\title{
E-ISSN 2602-2834
}

\section{PROBİYOTİK- İNSAN BAĞIŞIKLIK SİSTEMİ ETKİLEŞİMLERİ}

\author{
Dicle Dilara Akpınar ${ }^{1}$ D, Burcu Kaplan Türköz ${ }^{2}$ (D)
}

\section{Cite this article as:}

Akpınar, D.D., Kaplan Türköz, B. (2019). Probiyotik-innsan bağışıklık sistemi etkileşimleri. Food and Health, 5(4), $265-280$.

https://doi.org/10.3153/FH19027

${ }^{1}$ Ege Üniversitesi, Fen Bilimleri Enstitüsü Gıda Mühendisliği Bölümü, Bornova, 35040, İzmir, Türkiye

2 Ege Üniversitesi, Mühendislik Fakültesi Gıda Mühendisliği Bölümü, Bornova, 35040, İzmir, Türkiye

\section{ORCID IDs of the authors:}

D.D.A. 0000-0002-8318-169X

B.K.T. 0000-0003-3040-3321

Submitted: 06.02.2019

Revision requested: 05.05 .2019

Last revision received: 09.05 .2019

Accepted: 10.05.2019

Published online: 04.09.2019

Correspondence:

Burcu KAPLAN TÜRKÖZ

E-mail: burcu.kaplan.turkoz@ege.edu.tr
ÖZ

Probiyotikler yeterli miktarda tüketildiklerinde sağlık üzerine yararlı etkiler gösteren canlı mikroorganizmalardır. Bu mikroorganizmalar, patojenlerle mücadele, epitel hücre kararlılığını sağlama ve bağışıklık sistemini düzenleyebilmeleri ile sağlık üzerine olumlu etkiler göstermektedirler. Bağışıklık düzenleyici, anti-inflamatuar, anti-mikrobiyal, anti-oksidan etkilerini, açığa çıkardıkları metabolitleriyle, ürettikleri moleküllerle ve hücre yapı bileşenleriyle sağlamaktadırlar. Peptidoglikan, teikoik asit, lipoteikoik asit, hücre yüzey polisakkaritleri, salgılanan proteinler ve yüzey proteinleri gibi probiyotik etken molekülleri doğal bağışıklıkta görevli reseptörler tarafından tanınarak bağışıklık sistemini harekete geçirmektedir. Yapılan çalışmalarla bu etken moleküllerinden bazılarının etki mekanizmaları aydınlatılmıştır.Bu derlemede probiyotiklerin, probiyotik-konak etkileşimleri için kullandıkları bilinen etken molekülleri hakkında ve etkileri üzerine bilgi verilmesi amaçlanmıştır.

Anahtar Kelimeler: Probiyotikler, Sağlık etkileri, Probiyotik-konak etkileşimleri, Bağışıklık düzenleme, Etken moleküller

\section{ABSTRACT \\ PROBIOTIC-HUMAN IMMUNE SYSTEM INTERACTIONS}

Probiotics are live microorganisms which when administered in adequate amounts confer a health benefit on the host. These microorganisms are known to provide beneficial health effects by competing with pathogens, providing epithelial cell stability and showing regulatory effects on the immune system. They provide immunomodulatory, anti-inflammatory, anti-microbial, antioxidant effects with their released metabolites, produced molecules and cell structure components. Effector molecules of probiotics such as peptidoglycan, teichoic acid, lipoteichoic acid, cell surface polysaccharides, secreted proteins and surface proteins are recognized by innate immunity receptors and activate the immune system. The mechanisms of some effector molecules of probiotics have been elucidated. The aim of this review is to give information on the effects of probiotics and their active molecules known to be used for probiotic-host interactions.

Keywords: Probiotics, Health Effects, Probiotic-host interactions, Immunomodulation, Effector molecules 


\section{Giriş}

Dost mikroorganizmalar olarak adlandırılan probiyotikler, FAO/WHO tarafindan yeterli miktarda tüketildiklerinde insan sağlığına yararlı etkileri olan canlı mikroorganizmalar olarak tanımlamaktadır (FAO/WHO, 2002). Bulgarlar' in sağlıklı ve uzun yaşam sürmelerinin sırrını merak eden Elie Metchnikoff 1900' lü yılların başlarında probiyotiklerin sağlık üzerine yararlı etkilerinin olduğunu gösteren ilk araştırmayı yapmış ve yapılacak diğer çalışmaların da yolunu açmıştır. Yapılan araştırmalarla, fermente süt ürünleri tüketimi ile sağlıklı yaşam ilişkilendirilmiş ve bu etkinin kaynağının fermente süt ürünlerinde bulunan bu dost bakteriler olduğu ispatlanmıştır (Villena vd., 2013; Nagpal vd., 2014). Tablo 1' de bir bakterinin probiyotik olabilmesi için sahip olmas1 gereken özellikler verilmiştir.

Probiyotiklerin insan sağlı̆̆ üzerine etkileri farklılık gösterebilmektedir. Tüketilen probiyotik bakteri suşu ve sayısı, probiyotik ürünün formulasyonu, tüketen bireyin bağırsak mikroflorası ve metabolik durumuna göre etkiler değişiklik göstermektedir. $\mathrm{Bu}$ nedenle, tüketilen probiyotik ürünün herkeste aynı etkiyi göstermesi beklenmemektedir (Corcoran vd., 2008).

Probiyotiklerin yararlı etkilerinin ortaya çıkabilmesi için bağırsaklara yeterli sayıda ulaşmaları gerekmektedir. Probiyotikler, çoğunlukla Lactobacillus ve Bifidobacterium cinsle- rinden oluşmakta ve ticari olarak kullanılmaktadır. İlk probiyotik ticari ürün olarak, 1930' larda Lactobacillus casei Shirota suşunu içeren probiyotik süt ürünü 'Yakult' piyasaya sürülmüş ve sonrasında diğer birçok probiyotik ürün ticarileştirilmeye başlamıştır (Villena vd., 2013; Nagpal vd., 2014). Ticari probiyotik ürünlerin artmasıyla, Türk Gıda Kodeksinde 29/12/2011 tarihli 28157 sayılı yönetmeliğe göre ürünün probiyotik ürün olabilmesi için içerisinde raf ömrü sonuna kadar yeterli miktarda canlı probiyotik mikroorganizma (en az 1.0x $10^{6} \mathrm{kob} / \mathrm{g}$ ) bulundurmas 1 ve bu canlılı̆̆ muhafaza etmesi gerektiği bildirilmiştir (G1da, Tarım ve Hayvancılık Bakanlığı, 2011).

Günümüzde tüketicilerin bilinçli ve sağlıklı beslenmeye yönelmesiyle probiyotiklerin önemi giderek artmaktadır. Sağlık üzerine etkileri sayesinde probiyotik ürünlere ticari olarak büyük yatırımlar yapılmış ve bu ürünler tüketici tercihine yönelik çeşitlendirilmiştir (Agrawal, 2005; Rodgers, 2008; Villena vd., 2013). Probiyotiklerin sağlık üzerine etkilerinin araştırılmasına yönelik çalışmalar yeni fonksiyonel probiyotik ürünlerin geliştirilmesine de ortam hazırlamıştır.

$\mathrm{Bu}$ derlemede genel olarak probiyotikler, probiyotiklerin sağlik üzerine etkileri ile ilintili moleküler mekanizmalar ve probiyotiklerin hem insan bağırsak epitel hücreleri hem de bağ $1-$ ş1klık hücreleriyle etkileşimlerini sağlamak için kullandıkları etken moleküller ile ilgili yapılan çalışmalar derlenmiştir.

Tablo1. Probiyotik Mikroorganizmaların Özellikleri

\begin{tabular}{|c|c|}
\hline Probiyotik Mikroorganizmaların Özellikleri & Referanslar \\
\hline Anti-alerjik, anti-toksik, anti-mutajenik ve anti-kanserojen & \multirow{11}{*}{$\begin{array}{l}\text { Ouwehand vd., 2002, } \\
\text { Sağdıç vd., 2004, Guarner } \\
\text { vd., 2005, } \\
\text { Singh vd., 2011, Sarkar, } \\
2013 \text {, } \\
\text { Nagpal vd., } 2014\end{array}$} \\
\hline Bağırsaklarda mukus ya da insan epitel hücrelerine yapışarak kolonizasyon & \\
\hline Bağırsakta patojen yapışmasını azaltma & \\
\hline B-galaktosidaz aktivitesi & \\
\hline Genetik stabilite & \\
\hline Kolay ve tekrar üretilebilme & \\
\hline Üretim ve depolama süresinde dayanıklılık & \\
\hline Patojenlere karşı antimikrobiyal aktivite & \\
\hline Patojen özellik taşımama & \\
\hline Sağllk üzerine yararlı etkiler & \\
\hline Sindirim enzimlerine, mide asidine ve safra tuzlarına karşı direnç & \\
\hline
\end{tabular}




\section{Probiyotiklerin Etki Mekanizmalari ve Sağlik Üze- rine Etkileri}

\section{Probiyotiklerin Etki Mekanizmalart}

Probiyotikler insan sağlığını doğrudan ya da dolaylı olarak etkilemektedir. Probiyotiklerin en temel etkileri arasında patojenlerle mücadele, bağışıklık sistemini yönlendirme ve bağırsak epitel bariyeri koruma ve iyileștirme sayılabilir (Lebeer vd., 2010).

Probiyotikler, bağırsak epitel hücrelerine tutunarak patojenlerin tutunmasinı ve besin rekabetine girerek patojenlerin gelişimini engellerler (Sarkar, 2013). Probiyotikler, ayrıca ürettikleri anti-mikrobiyal maddelerle (defensin, bakteriyosin ve/veya hidrojen peroksit) ve ürettikleri organik asitlerin ortam pH' sını düşürmesiyle patojenlerin gelişimini baskılarlar (Nagpal vd., 2014). Örneğin; kronik gastrite neden olan patojen Helicobacter pylori' nin tedavisindeki antibiyotik uygulamalarıyla beraber probiyotik kullanımının, $H$. pylori' nin mide epitelinde kolonizasyonunu önleyerek inflamasyonu azalttığ 1 bilinmektedir (Gotteland vd., 2006).

Probiyotikler, ürettikleri moleküllerle ya da hücre yapı bileşenlerini kullanarak bağırsaklarla doğrudan etkileşime girerek bağ $1 s ̧ 1 k l 1 k$ sistemini düzenleyebilmektedirler (Boirivant ve Strober, 2007; Villena vd., 2013). Peptidoglikan, lipopolisakkarit, teikoik asit, lipoteikoik asit, bakteriyal DNA, ekzopolisakkarit ve flagella (kamçı) gibi Mikrop İlişkili Moleküler Yapılar (MAMP) bağışıklık sisteminde görevli bu yapıları tanıyan reseptörlerle (desen tanıma reseptörü, PRR) etkileşime girerek doğal ve kazanılmış bağışıklık sistemini harekete geçirirler (Lee vd., 2013). Bu alanda kayda değer sayıda çalışma yapılmasına rağmen hala çözülememiş moleküler mekanizmalar mevcuttur. Ayrıca, her probiyotik suşunun bağışıklık etkisi farklıdır. Bu nedenle, her suşun spesifik olarak incelenerek etkileşim mekanizmalarının açığa çıkarılması gereklidir (Lebeer vd., 2008; Sarkar ve Mandal, 2016).

Son olarak, patojenlerin ürettikleri toksinlerle ve bağışıklık sistemi tarafindan patojenlere karşı üretilen pro-inflamatuar sitokinlerle epitel bariyer zarar görmekte ve epitel hücrelerin geçirgenliği artmaktadır. Böylece, patojenler ve istenmeyen metabolitler epitel bariyeri geçerek kan akışına karışmaktadır (Boirivant ve Strober, 2007; Sarkar ve Mandal, 2016; Gleeson, 2017). Probiyotikler çeşitli sinyal yolaklarını harekete geçirerek programlı hücre ölümlerinin önlenmesi, defensin üretimi, epitel hücreler arasındaki bağların güçlendirilmesi, mukus salınımının arttırılması gibi mekanizmaları tetikleyerek epitel hücrelerin kararlılığının sağlanmasına yardımcı olurlar (Lebeer vd., 2008; Lee vd., 2013; Krishna Rao ve Samak, 2013).

\section{Probiyotiklerin Sağlık Üzerine Etkileri}

Probiyotik tüketiminin sağlık üzerine birçok yararı olduğu bilinmektedir, hatta probiyotikler bazı hastalıklarda önleyici ve/veya tedavi edici olarak kullanılmaktadır. Probiyotiklerin sağlık üzerine etkilerini belirlemek için birçok klinik çalışma yapılmıştır. Ancak bu araştırmalar sonucunda bazı rahatsızlık ve hastalıklarda kesin olumlu etkileri belirlenebilmişken, bazıları üzerinde ise bu etkiler belirlenememiştir (Kleerebezem vd., 2019).

Probiyotiklerin önleyici ve/veya tedavi edici olarak kullanıldığı hastalıkların başında inflamatuar bağırsak hastalıkları (IBD) gelmektedir. Kronik, tekrarlayabilen ve çeşitli faktörlere bağlı olan IBD, sindirim sistemi boyunca bağ 1 şıklık sisteminin düzensiz ve aşırı yanıt vermesiyle inflamasyon oluşması nedeniyle görülen bir hastalıktır. Genetik faktörler, çevresel faktörler, bağışıklık sistemi bozuklukları, patojenler ve oksidatif stres IBD' nın oluşmasına neden olabilecek faktörlerdir (Boirivant ve Strober, 2007; Pandey vd., 2015). IBD' ler içerisinde yer alan ülserit kolit (UC), Crohn (CD) ve poşit hastalıklarının tedavisinde ve hastalık semptomlarının hafifletilmesinde probiyotik tüketiminin etkili olduğu yapılan klinik araștırmalarla gösterilmiștir (Sheil vd., 2007; Kelesidis ve Pothoulakis, 2012; Veerappan vd., 2012).

En yaygın fonksiyonel sindirim sistemi rahatsızlığı olan inflamatuar bağırsak sendromu (IBS), daha çok psikolojik, sosyal ve biyolojik faktörlerin etkili olduğu, yaşam kalitesini düşüren kronik bir rahatsızlıktır (Tanaka vd., 2011). Probiyotik tüketiminin IBS semptomlarını azaltıcı etkiler gösterdiği çalışmalarla belirlenmiş ancak bu etkilere sebep olan mekanizmalar tamamen aydınlatılamamıștır (Hoveyda vd., 2009; Tanaka vd., 2011; Pandey vd., 2015).

Probiyotiklerin tedavi yardımcısı olarak kullanıldığı başka bir sağlık problemi ishaldir. Antibiyotik kullanımı, patojen bakteriler ve virüsler bağırsak mikroflorasının değişmesine sebep olarak ishal olunmasina neden olabilir. Akut, antibiyotik kaynaklı ve seyahat ishali çeşitlerinin hepsinde probiyotik tüketiminin olumlu sonuçlar verdiği bilinmektedir (Macfarlane ve Cummings, 2002; Agrawal, 2005; McFarland, 2006; Sudha ve Bhonagiri, 2012; Pandey vd., 2015) .

Probiyotik tüketiminin, kolon kanseri riskini ve tümörlerini azaltıcı etki gösterdiği çalıșmalarla gösterilmiştir (Rafter, 2002; Fotiadis vd., 2008; Pandey vd., 2015). Probiyotiklerin ürettikleri anti-kanserojenik ve anti-mutajenik maddelerle tümör oluşumu ve kanser riskini azalttığı düşünülmektedir. Probiyotiklerin, bağırsaklarda oluşan kanserojen bileşikleri etkisiz hale getirmesi, bağırsak mikroflorasını değiştirerek kanserojen bileşik oluşumuna sebep olan mikroorganizmaların azalmasını sağlaması ve hücre döngüsüne yardımcı olan 
ve tümör hücrelerinin gelişimini engelleyen bileşenler üretmesi kanseri önleyici mekanizmaları olarak öne sürülmektedir. Ayrıca olası mekanizmalardan biri de bağışıklık cevabının probiyotikler tarafindan düzenlenmesi olarak gösterilmektedir (Rafter, 2002; Gürsoy ve Kinik, 2005; Parvez vd., 2006; Fotiadis vd., 2008; Kumar vd., 2010).

Probiyotiklerin bağırsak bariyer fonksiyonunu koruduğu ve bağışıklık yanıtının düzenlenmesi üzerine etkilerinin olduğu bilinmektedir. Probiyotiklerin bu mekanizmaları kullanarak alerji semptomlarının hafifletilmesi üzerine olumlu etkiler gösterdiği klinik çalışmalarla belirlenmiştir (Kalliomäki ve Isolauri, 2004; Parvez vd., 2006; Rupa ve Mine, 2012).

Probiyotikler, ayrica, laktoz intolerans1, gastrit, hipertansiyon, ağız sağlığı, obezite, diyabet, yüksek kolestrol, karaciğer hastalıkları ve çeşitli enfeksiyon hastalıkları üzerine olumlu etkiler göstermektedir. (Parvez vd., 2006; Singh vd., 2011; Rupa ve Mine, 2012; Nagpal vd., 2014; Pandey vd., 2015).

Probiyotiklerin sağlık üzerine olumlu etkilerinin moleküler mekanizmalarının belirlenmesi için yapılan araştırmalar son yıllarda hız kazanmıştır. Özellikle probiyotiklerin etken moleküllerinin belirlenmesi ve bu moleküllerin doğrudan hastalıkları önleyici ya da tedavi amacı ile kullanılması konusunda çalışmalar yapılmaktadır.

\section{Probiyotiklerin Etken Molekülleri}

Probiyotikler sağlık üzerine etkilerini hücre yapı bileşenleriyle, ürettikleri moleküllerle ve fermantasyon sonucu oluşan metabolitleriyle sağlamaktadır. Bu moleküller kısa zincirli yağ asitleri, peptitler, enzimler ve proteinler, teikoik asit, lipoteikoik asit, peptidoglikan, endo- ve ekzo- polisakkaritler, hücre yüzey proteinleri, vitaminler, organik asitler, flagella, fimbria, hidrojen peroksit ve karbondioksit olarak siralanabilir (Rupa ve Mine, 2012; Matsuki ve Pe, 2013; Tsilingiri ve Rescigno, 2013; Tabasco vd., 2014; Kang ve Im, 2015; Sarkar ve Mandal, 2016; Aguilar-Toalá vd., 2018). Şekil 1' de probiyotiklerin etken molekülleri şematik olarak gösterilmiştir.

Probiyotiklerin bağışıklık düzenleyici etkileri, probiyotik-konak etkileşimleriyle başlar. Bağışıklık sisteminin düzenlenmesi ve sürdürülmesi için; epitel hücrelerde ve bağışıklık hücrelerinde bulunan (makrofajlar, dendritik hücreler vb.) doğal bağ 1 şklıkta görevli PRR' ler çeşitli bakterilerde bulunan MAMP' ları tanır ve bağışıklık sisteminin sinyal iletimini başlatır (Akira vd., 2006; Kumar vd., 2009; Kawai ve Akira, 2011; Kumar vd., 2011). Probiyotiklerin peptidoglikan, teikoik asit, lipoteikoik asit, hücre yüzey polisakkaritleri, salg1lanan proteinler ve yüzey proteinleri gibi moleküllerinin PRR tarafından tanınarak doğal bağıșıklık sinyal iletimini başlattığ 1 son yıllarda yapılan çalışmalarla ortaya konmuştur (Lebeer vd., 2010; Bron vd., 2012b; Lee vd., 2013; Ruiz vd., 2014; Hevia vd., 2015).

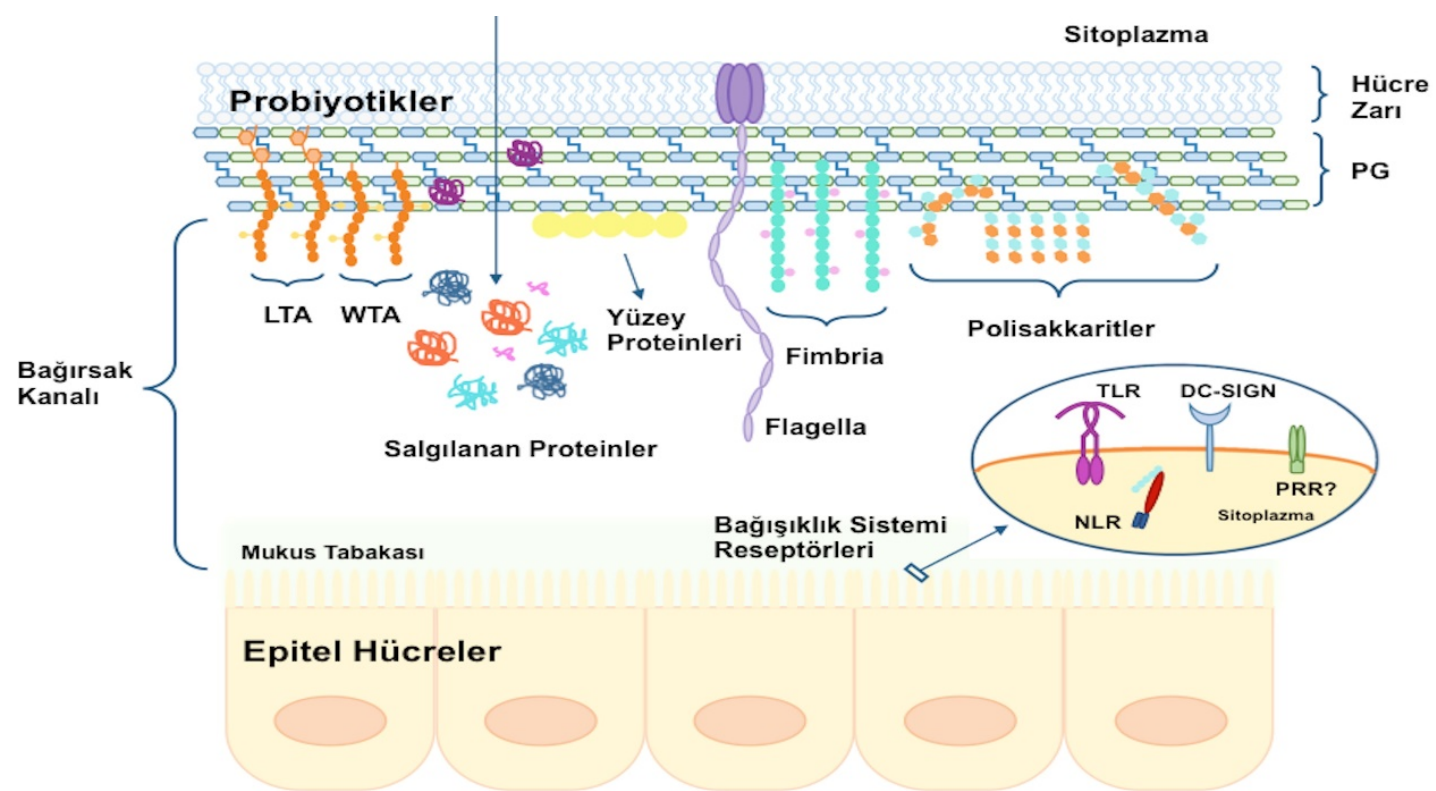

Şekil 1. Probiyotiklerin etken moleküllerinin şematik gösterimi. Soldan sağa, teikoik asit (LTA ve WTA), probiyotiklerin hücre dışına salgıladığı protein ve hücre yüzey proteinleri, flagella, fimbria, polisakkaritler (EPS, WPS ve CPS) ve peptidoglikan ile bağırsak epitellerinde bulunan bağışıklık sisteminde görevli PRR' ler (TLR, NLR ve DC-SIGN gibi reseptörler) etkileşime girerek bağışıklık yanıtını oluştururlar. 


\section{Peptidoglikan (PG)}

Gram (+) bakterilerde kalın bir tabaka olarak görülen peptidoglikan tabakası, glikan zincirlerine $\beta-1,4 \mathrm{~N}$-asetilglukozamin (GlcNAc) ve N-asetilmuramik asit (MurNAc) alt birimlerinin bağlanmasıyla oluşan ve hücreye şeklini verip hücre bütünlüğünü koruyan temel hücre duvarı bileșenidir (Delcour vd., 1999). PG üzerinde kovalent bağl1 teikoik asit, ekzopolisakkaritler ve proteinler yer almaktadır. PG yapısındaki farklı bağ oluşumlarına dayalı çeşitlilik bakteri suşlarına spesifik özellikler sağlar (Kleerebezem vd., 2010). PG' nin otolizi ve enzimatik parçalanmasıyla oluşan parçaları sindirim sisteminde yayılarak PRR' ler tarafından tanınırlar. PG parçalarının tanınmas1 TLR2 ve Nod-Benzeri Reseptörler (NLR 'ler) aracılığıla gerçekleşir (Lebeer vd., 2010). Probiyotik Lactobacillus plantarum ATCC 14917 ve Lactobacillus johnsonii JCM 2012 ile yapılan bir çalışmada, bu bakterilere ait peptidoglikan parçalarının pro-inflamatuar sitokin IL-12 üretimini TLR2 yoluyla baskılayıcı etki gösterilmiştir (Shida vd., 2009).

L. casei Shirota, Lactobacillus rhamnosus ATCC 53103, Lactobacillus plantrarum ATCC 14917 ve L. Johnsonii Y 50092 ile yapılan başka bir çalıșmada, izole edilen polisakkarit-PG komplekslerinin bağ 1 șiklık düzenleyici etkileri incelenmiștir. L. casei Shirota dıșındaki suşlar ile sonuç alınamazken, L. casei Shirota' dan izole edilen polisakkarit-PG kompleksinin pro-inflamatuar sitokin IL-6 üretimini düsürdüğ̈ ve anti-inflamatuar NF- $\kappa B$ yolağını başlattığ 1 gösterilmiştir. Böylece L. casei Shirota' nın IBD tedavilerinde yararlı bir probiyotik olabileceği ileri sürülmüştür (Matsumoto vd., 2005) .

NOD2 reseptörlerinin de PG türevi muramil peptitleri tan1dı ̆ı ve Crohn hastalığında NOD2 reseptörlerinin rol oynadı $\breve{g} 1$ bilinmektedir (Ogura vd., 2001; Girardin vd., 2003). Probiyotik Lactobacillus salivarius Ls33 ve Lactobacillus acidophilus NCFM bakterilerinden saflaştırılan PG' nin muramil peptit parçalarıyla kolit fareler üzerinde çalışma yapılmıştır. Yapılan çalışmada Ls33 PG' nin NOD2 sinyal iletimine bağlı olarak anti-inflamatuar sitokin IL-10 salınımını başlattığı ve bu yolla da koruyucu etki gösterdiği belirlenmiştir. NCFM' nin ise kolit fareler üzerinde herhangi bir koruyucu etki göstermediği görülmüştür. Bu sonuçlar, PG fragmanlarının NLR sinyal iletimi üzerine etkisini gösterirken, bu etkinin suşa spesifik olarak ortaya çıtı̆̆ını göstermiş ve PG yapısındaki çeşitliliğin öneminin anlaşılmasına olanak sağlamıştır (Fernandez vd., 2011).

\section{Teikoik Asit (TA)}

Gram $(+)$ bakterilerin hücre duvarlarının ikinci temel bileşeni teikoik asittir (TA). Anyonik bir bileșen olan TA, PG' ye tekrarlanan poligliserol fosfat ve poliribitol fosfat alt birimlerinin kovalent bağ ile bağlanmasıyla oluşmaktadır. TA hücre duvarına bağlı (WTA) ya da membrana bağlı (LTA) olarak bulunabilmektedir (Neuhaus ve Baddiley, 2003). LTA hemen hemen tüm Gram (+) bakterilerde bulunduğu için bağırsak epitel hücreleri LTA' ya karşı tolerans mekanizmaları geliştirmiştir (Melmed vd., 2003; Lebeer vd., 2010). TA bileşenlerinin mekanizmalarını belirlemeye yönelik çalışmalarda doğrudan canlı hücreyle ve izole edilen LTA' lar ile in vivo ve in vitro deneyler yapılmıştır. LTA' nın yapısındaki farkl1lıkların bağışıklık düzenleyici etkisi üzerine katkıları henüz netleştirilememiştir (Lee vd., 2013).

Gram (-) bakterilerin lipopolisakakritleriyle epitel hücrelerde pro-inflamatuar IL-8 sitokininin salınımına neden olduğu, $L$. johnsonii La1 ve L. acidophilus La10 probiyotik bakterilerinden izole edilen LTA' ların ise IL-8 salınımını baskıladığ gösterilmiştir. Bu çalışmayla, Lactobacillus suşlarının Gram (-) bakteri ve bileșenleri kaynaklı hastalıkların tedavisinde ve bağırsak homeostazının sağlanmasında rol oynayabileceği önerilmiștir (Vidal vd., 2002). Benzer șekilde, Staphylococcus aureus LTA' si ile indüklenen pro-inflamatuar TNF- $\alpha$ salınımına, L. plantarum 'dan izole edilen LTA' nın antagonistik etki gösterdiği ve TLR2 yoluyla TNF- $\alpha$ salınımını engellediği gösterilmiştir (Kim vd., 2008).

LTA' nın yapısal farklılıklarının mekanizmaları üzerine etkisini belirlemek için de çalışmalar yapılmıștır. L. plantarum L-137 ve L. plantarum JCM1149 suşlarının LTA' ları ile çalıșılmış ve daha iyi bir IL-12 indüktörü olan L-137 'nin LTA' sında daha fazla alanin olduğu bulunmuştur (Hirose vd., 2010). Alt1 farklı Lactobacillus suşuna ait LTA' ların fare bağ1şıklık hücreleri üzerine etkileri araştırılarak, $L$. casei ve Lactobacillus fermentum' dan izole edilen LTA' ların TLR2 yoluyla makrofajlarda pro-inflamatuar sitokin TNF- $\alpha$ salın1mını indüklediği, ancak doza ve suşa bağlı farklılıklar olduğu gösterilmiştir (Matsuguchi vd., 2003). L. acidophilus NCFM' nin LTA sentezleyen fosfogliserol transferaz geni çıkarılarak elde edilen mutant LTA ile pro-inflamatuar IL-12 ve TNF- $\alpha$ salınımını azalırken, anti-inflamatuar IL-10 salınımının arttığ 1 görülmüştür. Böylece, LTA' nın IL-12 salınımındaki temel faktör olduğu doğrulanmıştır (Saber vd., 2011; Mohamadzadeh vd., 2011). Ayrica NCFM 'nin LTA' s1 ile kolon kanseri olan farelerde yapılan çalışmalar polipleri hafifletici etkisi olduğunu göstermiştir (Khazaie vd., 2012). Kronik kolit olan farelerle yapılan çalışmada, L. rhamnosus GG' nin LTA' sinın D-alanizasyonundan sorumlu dlt geninin inaktivasyonuyla mutantlar elde edilmiştir. Bu mutantların TLR 
ekpresyonunu ve pro-inflamatuar sitokin üretimini azaltıc1 etki gösterdiği belirlenmiştir (Claes vd., 2010; Claes vd., 2012).

Bağışıklık cevabı oluşturulurken, IL-10 (anti-inflamatuar)/ IL-12 (pro-inflamatuar) sitokin salınımı arasındaki denge kritik bir öneme sahiptir. Farklı Lactobacillus suşları IL-10 veya IL-12 salınımını farklı seviyelerde indüklemektedirler. $L$. plantarum IL-10 salınımını indüklerken, zayıf olarak IL-12 indüksiyonu da yapmıştır. L. plantarum' un tersine, L. casei IL-12 salınımını indüklerken, zayıf olarak IL-10 indüksiyonu yapmıştır. İki suşun beraber kullanımıyla yapılan çalışmada, makrofajların aktivasyonunu sağlayan WTA ve LTA' nın TLR2 yoluyla IL-10 üretimini sağlayarak sinerjik etki oluşturdukları görülmüştür (Kaji vd., 2010).

Yapılan araştırmaların çoğu LTA' nın bağ etkisini belirlemeye yöneliktir. Diğer bir hücre duvarı bileşeni olan WTA' nın etki mekanizmasını anlamaya yönelik yapılan bir çalışmada, WTA üretmeyen L. plantarum WCFS1 mutant1, L. plantarum WCFS1 WTA's1 ve D-Alanin eksikliği bulunan L. plantarum WCFS1 WTA mutantı üzerine çalış1mıştır. Mutant ve doğal suşa ait WTA' nın TLR2/6 sinyal yolunu doğrudan etkilemediği görülmüştür. Saflaştırılan WTA' lar insan dentrik hücrelerinde herhangi bir sitokin üretimine neden olmazken, pro-inflamatuar sitokin IL-12 ve TNF- $\alpha$ salınımınlarını önemli seviyede azalttığı belirlenmiştir (Bron vd., 2012a). Bu çalışmada da görüldüğü gibi, WTA 'nın mekanizması üzerine kesin bir sonuca varılamadığı için, bağışıklık düzenleyici etkisini belirlemeye yönelik araştırmalar yapılmaya devam edilmelidir.

\section{Hücre Duvarı Polisakkaritleri}

Hücre duvarı polisakkaritleri, hücre yüzeyine gevşekçe bağlı bulunan ve çevreye salınabilen formda (ekzopolisakkaritlerEPS), daimi olarak hücreye bağlı ve kalınca etrafını örtecek formda (kapsüler polisakkaritler- CPS ) ve hücre duvarını örtmeyecek şekilde kovalent bağlı olarak tutunmuş ya da tutunmamış formda (hücre duvarı polisakkaritleri- WPS) olarak s1nıflandırılırlar. Polisakkaritlerin konumu ve miktarı bakterinin büyüme koşullarına ve bakteri türüne/suşuna bağlı olarak değişmekte ve dolayısıyla WPS, CPS ve EPS' de fazlasıyla rastgele farklılaşmalara olanak sağlamaktadır. Genellikle heteropolisakkarit kompleksi yapısında olan polisakkaritlerdeki farklılaşmayı belirleyen faktörler; şeker monomeri çeşidi, bağlanma ve dallanma şekilleri ve modifikasyonlar olarak s1ralanabilir (Kleerebezem vd., 2010; Chapot-Chartier ve Kulakauskas, 2014). Son yapılan çalışmalarda, probiyotik polisakkaritlerinin bağırsak kolonizasyonunda önemli rolü olduğu ve sindirim sistemi koşullarına karşı koruyucu etki gösterdiği bulunmuştur (Mozzi vd., 2009).
Polisakkaritlerin doğrudan bağışıklık düzenleyici etkisi olduğunu gösteren çalışmalar mevcuttur. L. casei Shirota hücre duvarı polisakkaritlerinin makrofajların ürettiği pro-inflamatuar IL-12 sitokin üretimini durdurarak pro-inflamatuar yanıt1 baskıladığ1 gösterilmiştir (Yasuda vd., 2008). Escherichia coli Nissle 1917' in CPS 'sinin fonksiyonunu belirlemeye yönelik yapılan çalışmada, $E$. coli Nissle 1917 ve kapsülsüz $E$. coli Nissle 1917 mutanlarıyla çalışılmıştır. İki suşta ile de pro-inflamatuar sitokin indüksiyonu görülmesine rağmen, kapsül içermeyen mutantın pro-inflamatuar sitokin ekpresyonunda ciddi şekilde azalma olduğu ve E. coli Nissle 1917' den saflaştırılan CPS' nin sitokin üretimini indüklemediği belirlenmiştir. Bu sonuçlar doğrultusunda, CPS' nin bağırsak epitel hücreleriyle bakteri hücresinin etkileşimine aracılık ettiği gösterilmiş ancak mekanizması henüz belirlenememiştir (Hafez vd., 2009). L. rhamnosus GG EPS' sinin bakteriyi sindirim sisteminde önemli ölçüde koruyucu etki gösterdiği ve bağ 1 şıklık sistemi tepkisine karşı EPS üretiminin arttığ1 gösterilmiştir (Lebeer vd., 2011).

Probiyotik EPS' nin bağ 1 şılılı sistemini etkilemesinin patojenlerle mücadelede dolaylı olarak önemli bir faktör oldugunu gösteren çalışmalar yapılmıştır. Bifidobacterium breve UCC2003 EPS' sinin fare modellerinde pro-inflamatuar sitokin üretimini baskıladığ1 ve böylece, Citrobacter rodentium kaynaklı enfeksiyonu azalttığı belirlenmiştir (Fanning vd., 2012). Benzer şekilde, L. plantarum N14' den saflaştırılan EPS' lerin domuz bağırsak epitellerinde enteratoksik $E$. coli 'nin neden olduğu inflamasyona karşı pro-inflamatuar sitokin IL-6, IL-8 ve MCP-1 üretimini azalttığ1 görülmüştür. Sonuçlar doğrultusunda, domuzlarda patojen kaynaklı bağırsak enfeksiyonlarına karşı koruyucu etkisi olduğu belirlenmiştir (Murofushi vd., 2015). Bifidobacterium longum BCRC 14634 'ten izolen edilen EPS fraksiyonunun bağgşıklık düzenleme etkisine yönelik çalışmada, IL-10 anti-inflamatuar sitokin üretimini arttırdı ğ 1 ve in vitro makrofaj gelişimini teşvik ettiği gösterilmiştir (Wu vd., 2010). L. rhamnosus KL37 EPS' lerinin ise diğerlerinden farklı olarak fare makrofajlarından hem pro-inflamatuar sitokin TNF- $\alpha$, IL-6 ve IL-12 üretimini hem de anti-inflamatuar sitokin IL-10 üretimini uyardığ1 görülmüştür. TNF- $\alpha /$ IL-10 arasındaki dengenin incelenmesiyle potansiyel pro-inflamatuar etki gösterdiği belirlenmiş ve patojen enfeksiyonlarında klinik olarak bağ 1 şıklık düzenleyici ajan olarak kullanılabileceği önerilmiştir (Ciszek-Lenda vd., 2011). Başka bir çalışmada da, Bifidobacterium animalis ssp. lactis A1 ve IPLA-R1, B. longum NB667 ve L. rhamnosus GG' nin ürettikleri EPS' lerin bakteriyel patojenlerin toksik etkisini yok ettiği belirlenmiştir (Ruas-Madiedo vd., 2010). 


\section{Hücre Yüzeyinde Bulunan ya da Hücre Dıșına Sentezlenen Proteinler}

Hücre yüzeyine tutunmuş halde olan ve hücre dışına salgılanan proteinler/peptitler mikroorganizma-konak hücre etkileşimlerinde önemli rol oynar (Lebeer vd., 2010). Bu peptitlerden biri olan Serin-Treonince zengin peptit (STp) L. plantarum BMCM12 tarafindan üretilmektedir. STp' nin mekanizmasının aydınlatılması için bağırsakta bağışıklık cevabı/tolerans1 arasındaki mekanizmayı kontrol eden dentrik hücreler ile çalışılmış ve STp' nin anti-inflamatuar IL-10 salınımını artırdığı görülmüştür (Bernardo vd., 2012). Ayrıca STp' nin kolit hastalarında bağısak homeostazının sağlanmasına yardımcı olduğu bildirilmiştir (Al-Hassi vd., 2014 ).

Hücre dişına sentezlenen bir serin proteaz inhibitörü olan serpin genom taramalarıla $B$. Longum sekansında bulunmuş (Schell vd., 2002) ve saflaştırılan serpinin, serin pankreatik elastaz ve nötrofil elastazını inhibe ederek inflamasyonu ortadan kaldırdığı görülmüştür. Böylece bağırsak homeostazına katk1 sağladığ1 gösterilmiştir (Ivanov vd., 2006).

Hücre dişına sentezlenen bir diğer protein ise Lactobacillus paracasei tarafından üretilen proteaz lactocepindir. Lactocepin, pro-inflamatuar IFN-y' y1 indükleyerek epitel hücrelerce salınan IBD' de de görülen temel pro-inflamatuar kemokin olan IP-10 proteinini parçalamakta ve böylece anti-inflamatuar etki göstermektedir. Lactocepin üreten L. paracasei ve lactocepin üretemeyen L.paracasei mutantıyla yapılan çalışmada, mutantın IP-10' u daha az parçaladığ 1 belirlenmiş ve böylece lactocepinin bağ $1 s ̧ 1 k l 1 k$ düzenleyici etkisi ortaya konmuştur (Von Schillde vd., 2012).

Probiyotikler bağırsakta hücre dışına anti-mikrobiyal proteinler ya da bakteriyosinlerini salgilarlar. Patojen enfeksiyonlarının önlenmesinde yer alan bakteriyosinlerin etkilerini belirlemek için, patojen Listeria monocytogenes enfeksiyonuna karş1 L. salivarius UCC118' un ürettiği bakteriyosin Abp18 ile çalışılmıştır. Abp18 üretmeyen mutantın aksine doğal suşun farelerde konakla doğrudan etkileşime geçerek enfeksiyona karş1 koruyucu etki gösterdiği görülmüştür (Corr vd., 2007). Ayrıca, bazı L. plantarum bakteriyosinlerinin doğrudan anti-inflamatuar sitokin üretimine etkisi olduğu gösterilmiştir (Meijerink vd., 2010; Van Hemert vd., 2010).

Probiyotiklerin ürettikleri proteinlerle bağışıklık düzenleyici etki mekanizmalarının araştırılmasına öncü olan çalışmalardan birinde; VSL\#3 probiyotik karıșımındaki probiyotiklerin ve ürettikleri proteinlerin, epitel bariyer fonksiyonuna katk1 sağladı ̆̆1 belirlenmiștir (Otte ve Podolsky, 2004; Lee vd., 2013). Bu katkının L. rhamnosus GG' nin ürettiği 2 adet proteinden, (p40 ve p75) kaynaklı olduğu sonraki çalışmalarla gösterilmiştir. p40 ve p 75 proteinlerinin, insan ve fare bağırsak epitel hücrelerinde spesifik sinyal iletimi yoluyla programlı hücre ölümlerini (apoptosis) önlediği, epitel hücrelerin çoğalmasını teşvik ettiği ve epitel zararları azalttığı görülmüştür (Yan vd., 2007; Yan vd., 2013, Seth vd., 2008). Böylece, probiyotik proteinlerin doğrudan bağırsak epitel hücre homeostazına katkı sağladıkları ortaya konmuștur. Yapılan genomik araştırmalarla, L. casei, L. paracasei ve L. rhamnosus suşlarının genomlarında p40 ve p75 genlerini kodlayan diziler bulunmuş ve benzer rollere sahip oldukları gösterilmiştir. Böylece probiyotiklerin ürettiği hücre dış1 proteinlerin de probiyotik etkilerin oluşmasında rol oynadığı anlaşımıştır (Bäuerl vd., 2010).

Probiyotikler ürettikleri yüzey proteinleri ile de bağışıklık sistemiyle etkileşime girmektedir. L. acidophilus NCFM tarafindan üretilen yüzey proteini SlpA dendritik hücreye bağlanarak anti-inflamatuar sitokin IL-10 üretimini arttırırken pro-inflamatuar sitokin IL-12 üretimini düşürdüğü belirlenmiştir. Mutasyon çalışmalarıyla SlpA üretmeyen suşların dentrik hücre lektin reseptörlerine (DC-SIGN) bağlanmasında azalma olduğu görülmüsşür. Yapılan çalışmada, saflaştırılan SlpA' nın doğrudan DC-SIGN' a bağlanmasıyla etkileşimleri doğrulanmış ve DC-SIGN' a bağlanan ilk probiyotik bakteri ligandı olarak tanımlanmıştır (Konstantinov vd., 2008). Daha sonra yapılan çalışmalar ile L. acidophilus NCK2 187 ürettiği SlpA proteinin de benzer fonksiyonel özellikler gösterdiği ortaya konmuştur (Lightfoot vd., 2015).

Probiyotik Lactobacillus helveticus R0052' den ekstrakte edilen SlpA ile yapılan çalışmadaysa, patojenlerin bağırsak epitel hücrelerine yapışmasında azaltıcı etkisi olduğu gösterilmiştir (Johnson-Henry vd., 2007). L. helveticus fb213, L. acidophilus fb116 ve L. acidophilus fb214 suşları ile yapılan çalışmalarda SlpA üretmeyen mutantların epitel hücre yapışma kapasitelerinin azaldığı gösterilmiştir (Meng vd., 2014). Genomik yaklaşımlar kullanılarak yapılan taramalarda da, genelde yapışmada rollü olan çeşitli olası Slp proteinlerinin L. acidophilus, L. helveticus, L. brevis, L. gasseri, L. johnsonii, L. crispatus, L. kefir, L. parakefir, L. amylovorus, $L$. sobrius, ve $L$. mucosae' nin genomlarında bulunduğu tespit edilmiştir (Kleerebezem vd., 2010; Hynönen ve Palva, 2013 ).

Lactobasillerin ve VSL\#3 probiyotik kokteylinin pro-inflamatuar sinyal yolağını indükleyerek, insanda doğal bağışıklığın cevabı olarak üretilen ve antimikrobiyal bir peptit olan $\beta$ defensin-2 geninin indüksiyonuna yol açtığı gösterilmiştir. Ancak bu etkiyi sağlayan molekülün ne olduğu belirlenememiştir (Schlee vd., 2008). E. coli Nissle 1917 flagellalıdır ve $\beta$-defensin-2 salınımını indüklediği bilinmektedir. Flagella 
çeşitli bakterilerde hücre duvarına bağlı olarak bulunur. Konağın bağırsak epitel hücre reseptörleriyle ilk temasa geçtiği hareketli yüzey proteinidir (Ruiz vd., 2014). Yapılan çalışmada, flagellası olmayan E. coli Nissle 1917 mutantlarında bağışıklık düzenleme kapasitesi bozulurken, flagellanın tekrar aktifleştirilmesiyle bağışıklık düzenleme kapasitelerinin eskiye döndüğü belirlenmiştir. Başka bir $E$. coli suşunun $E$. coli Nissle 1917' nin tersine $\beta$-defensin-2 salınımını indüklemediği görülmüş, dolayısıyla, E. coli Nissle 1917' nin flagellasının temel uyarıcı faktör olduğu doğrulanmıştır (Schlee vd., 2007).

Probiyotiklerde hücre duvarına bağlı olarak bulunan bir diğer protein ise fimbria (pili)' dır. Biyosentez ve yapılarının farklı olmasına rağmen hem Gram (+) hem de Gram (-) bakterilerde fimbria görülmektedir. Genom sekanslarından yola çıkarak bifidobakter ve lactobasillerde fimbrianın kodlandığ 1 açığa çıkarılmıştır (Lebeer vd., 2010). Fimbrianın bağırsak epitel hücrelerine yapışabilme özelliği sağlamasının yanı sıra bağ1şıklığı uyarıcı özelliğinin de belirlendiği çalışmalar mevcuttur. Sağlik üzerine etkileri ve bağırsak epitellerine yapışabilme özelliği bilinen L. rhamnosus GG' nin hücre yüzeyinde bulunan fimbriaları ile bunu sağladığı bilinmektedir (Reunanen vd., 2012). Model olarak kullanılan L. rhamnosus GG ve fimbriası olmayan mutantlarıyla çalıșılmıș, fimbrianın epitel hücrelere bağlanmada önemli olduğu ve pro-inflamatuar sitokin IL-8' in ekspresyonunun dengelenmesinde fonksiyonel rolü olduğu belirlenmiștir (Lebeer vd., 2012). Benzer șekilde, L. rhamnosus GG' nin fimbriasının makrofajlar üzerindeki etkisi fimbriası olmayan L. rhamnosus GG mutantı ve doğal suşlarıyla çalışılarak fare modellerinde incelenmiştir. Fimbrianın makrofajlara bağlanmada önemli olduğu ve anti-inflamatuar sitokin IL-10 salınımını arttırarak ve pro-inflamatuar sitokin IL-6 salınımını azaltarak anti-inflamatuar etki gösterdiği görülmüştür (Vargas García vd., 2015). Aynı zamanda $L$. rhamnosus GG' nin patojen enfeksiyonları üzerine etkisine bakılmıș, Salmonella enterica serovar Typhimurium SL1344' nin neden olduğu inflamasyona karşı, fimbriasıyla bağırsak epitellerine bağlanıp doğal bağışıklık sitokin salınımını doğrudan uyardı ğı belirlenmiştir (Ganguli vd., 2015). $L$. rhamnosus GG' nin fimbrialarının patojen bakterilerin bağlanmasını önlediği belirtilerek, enfeksiyonlara karşı L. rhamnosus GG' nin fimbriasının tedavi amaçlı kullanılabileceği önerilmiştir (Tytgat vd., 2016). Bifidobacterium bifidum PRL2010 'nin fimbriası ile de çalışılmış, benzer şekilde fimbrianın yapışmada kritik önemi olduğu ve böylece bağırsak epitel hücre reseptörleriyle etkileşime girerek bağ $1 s ̧ 1 k l 1 k$ düzenleyici etki gösterdikleri belirtilmiştir (Turroni vd., 2013).

\section{Sonuc}

Son yıllarda yapılan çalışmalarla, probiyotiklerin bağışıklık sistemi üzerine birçok etkilerini ürettikleri moleküllerin insan hücreleri ile etkileşimleri sonucu sağladıkları ortaya çıkmıştır. Probiyotik hücre yapı bileşenleri ve ürettikleri moleküllerin bağışıklık sistemini yönlendirme mekanizmalarının belirlenmesi için birçok çalışma yapılmıştır. Sonuçlar probiyotiklerin insan bağışıklık sistemi üzerine aynı anda birçok etkiyi gerçekleştirebildiklerini göstermektedir. Probiyotiklerin tüketimiyle kesin sonuçların ön görülememesi nedeniyle, hastalıkların önleme ve tedavisinde probiyotiklerin değil ürettikleri etken moleküllerinin tüketiminin daha kontrollü bir yaklaşım olduğu anlaşılmaktadır. Bu da sentetik probiyotik etken moleküllerinin ilaç ya da gıda takviyesi olarak yakın zamanda hayatımıza gireceğini işaret etmektedir. Moleküler bilimlerle desteklenen, protein yapı çözümlemesi ve genomik gibi yaklaşımlar probiyotiklerin etken moleküllerinin ve etki mekanizmalarının belirlenmesine olanak sağlayacaktır.

\section{Etik Standart ile Uyumluluk}

Çıkar çatışması: Yazarlar bu yazı için gerçek, potansiyel veya algılanan çıkar çatışması olmadığını beyan etmişlerdir.

Teşekkür: Bu derlemedeki bilgi birikiminin oluşmasına katkı sağlayan TÜBITTAK-KBAG (Proje No: 116Z299) ve Ege Üniversitesi Bilimsel Araştırma Projesi (Proje No: 16-Müh-083) desteklerine teşekkür ederiz.

\section{Kaynaklar}

Agrawal, R. (2005). Probiotics: An emerging food supplement with health benefits. Food Biotechnology, 19(3), 227246.

https://doi.org/10.1080/08905430500316474

Aguilar-Toalá, J.E., Garcia-Varela, R., Garcia, H.S., Mata-Haro, V., González-Córdova, A.F., Vallejo-Cordoba, B., Hernández-Mendoza, A. (2018). Postbiotics: An evolving term within the functional foods field. Trends in Food Science \& Technology, 75, 105-114.

https://doi.org/10.1016/j.tifs.2018.03.009

Akira, S., Uematsu, S., Takeuchi, O. (2006). Pathogen recognition and innate immunity. Cell, 124(4), 783-801. https://doi.org/10.1016/j.cell.2006.02.015 
Al-Hassi, H.O., Mann, E.R., Sanchez, B., English, N.R., Peake, S.T.C., Landy, J., Man, R., Urdaci, M., Hart, A. L., Fernandez-Salazar, L., Lee, G.H., Garrote, J.A., Arranz, E., Margolles, A., Stagg, A.J., Knight, S.C., Bernardo, D. (2014). Altered human gut dendritic cell properties in ulcerative colitis are reversed by Lactobacillus plantarum extracellular encrypted peptide STp. Molecular Nutrition and Food Research, 58(5), 1132-1143.

https://doi.org/10.1002/mnfr.201300596

Bäuerl, C., Pérez-Martínez, G., Yan, F., Polk, D.B., Monedero, V. (2010). Functional analysis of the p40 and p75 proteins from lactobacillus casei BL23. Journal of Molecular Microbiology and Biotechnology, 19, 231-241.

https://doi.org/10.1159/000322233

Bernardo, D., Sánchez, B., Al-Hassi, H.O., Mann, E.R., Urdaci, M.C., Knight, S.C., Margolles, A. (2012). Microbiota/host crosstalk biomarkers: Regulatory response of human intestinal dendritic cells exposed to Lactobacillus extracellular encrypted peptide. PLoS ONE, 7(5), 1-8.

https://doi.org/10.1371/journal.pone.0036262

Boirivant, M., Strober, W. (2007). The mechanism of action of probiotics. Current Opinion in Gastroenterology, 23(6), 679-692.

https://doi.org/10.1097/MOG.0b013e3282f0cffc

Bron, P.A., Tomita, S., van Swam, I.I., Remus, D.M., Meijerink, M., Wels, M., Okada, S., Wells, J.M., Kleerebezem, M. (2012a). Lactobacillus plantarum possesses the capability for wall teichoic acid backbone alditol switching. Microbial Cell Factories, 11(123), 1-15.

https://doi.org/10.1186/1475-2859-11-123

Bron, P. A., Van Baarlen, P., Kleerebezem, M. (2012b). Emerging molecular insights into the interaction between probiotics and the host intestinal mucosa. Nature Reviews Microbiology, 10, 66-78.

https://doi.org/10.1038/nrmicro2690

Chapot-Chartier, M.P., Kulakauskas, S. (2014). Cell wall structure and function in lactic acid bacteria. Microbial Cell Factories, 13(1), 1-23.

https://doi.org/10.1186/1475-2859-13-S1-S9
Ciszek-Lenda, M., Nowak, B., Śróttek, M., Gamian, A., Marcinkiewicz, J. (2011). Immunoregulatory potential of exopolysaccharide from Lactobacillus rhamnosus KL37. Effects on the production of inflammatory mediators by mouse macrophages. International Journal of Experimental Pathology, 92(6), 382-391.

https://doi.org/10.1111/j.1365-2613.2011.00788.x

Claes, I.J.J., Segers, M.E., Verhoeven, T.L.A., Dusselier, M., Sels, B.F., De Keersmaecker, S.C.J., Sigrid, C.J., Vanderleyden, J., Lebeer, S. (2012). Lipoteichoic acid is an important microbe-associated molecular pattern of Lactobacillus rhamnosus GG. Microbial Cell Factories, 11(161), 1-8. https://doi.org/10.1186/1475-2859-11-161

Claes, I.J.J., Lebeer, S., Shen, C., Verhoeven, T.L.A., Dilissen, E., De Hertogh, G., Bullens, D.M.A., Ceuppens, J.L., Van Assche, G., Vermeire, S., Rutgeerts, P., Vanderleyden, J., De Keersmaecker, S.C.J. (2010). Impact of lipoteichoic acid modification on the performance of the probiotic Lactobacillus rhamnosus GG in experimental colitis. Clinical and Experimental Immunology, 162(2), 306-314. https://doi.org/10.1111/j.1365-2249.2010.04228.x

Corcoran, B. M., Stanton, C., Fitzgerald, G., Ross, R. P. (2008). Life Under Stress : The Probiotic Stress Response and How it may be Manipulated. Current Pharmaceutical Design, 14(14), 1382-1399.

https://doi.org/10.2174/138161208784480225

Corr, S.C., Li, Y., Riedel, C.U., O'Toole, P.W., Hill, C., Gahan, C.G.M. (2007). Bacteriocin production as a mechanism for the antiinfective activity of Lactobacillus salivarius UCC118. PNAS, 104(18), 7617-7621.

https://doi.org/10.1073/pnas.0700440104

Delcour, J., Ferain, T., Deghorain, M., Palumbo, E., Hols, P. (1999). The biosynthesis and functionality of the cell-wall of lactic acid bacteria. Antonie van Leeuwenhoek, 76, 159-84. https://doi.org/10.1023/A:1002089722581

Fanning, S., Hall, L.J., Cronin, M., Zomer, A., MacSharry, J., Goulding, D., O'Connell Motherway, M., Shanahan, F., Nally, K., Dougan, G., van Sinderen, D. (2012). Bifidobacterial surface-exopolysaccharide facilitates commensal-host interaction through immune modulation and 
pathogen protection. Proceedings of the National Academy of Sciences, 109(6), 2108-2113.

https://doi.org/10.1073/pnas.1115621109

FAO/WHO. (2002). Guidelines for the evalution of probiotics in food. Food and Agriculture Organization of the United Nations/World Health Organization, London, Ontario. p. 413-426.

Fernandez, E.M., Valenti, V., Rockel, C., Hermann, C., Pot, B., Boneca, I.G., Grangette, C. (2011). Anti-inflammatory capacity of selected lactobacilli in experimental colitis is driven by NOD2-mediated recognition of a specific peptidoglycan-derived muropeptide. Gut, 60, 1050-1059.

https://doi.org/10.1136/gut.2010.232918

Fotiadis, C.I., Stoidis, C.N., Spyropoulos, B.G., Zografos, E.D. (2008). Role of probiotics, prebiotics and synbiotics in chemoprevention for colorectal cancer. World Journal of Gastroenterology, 14(42), 6453-6457.

https://doi.org/10.3748/wjg.14.6453

Ganguli, K., Collado, M.C., Rautava, J., Lu, L., Satokari, R., Von Ossowski, I., Reunanen, J., De Vos, W.M., Palva, A., Isolauri, E., Salminen, S., Walker, W.A., Rautava, S. (2015). Lactobacillus rhamnosus GG and its SpaC pilus adhesin modulate inflammatory responsiveness and TLR-related gene expression in the fetal human gut. Pediatric Research, 77, 528-535.

https://doi.org/10.1038/pr.2015.5

Girardin, S.E., Boneca, I.G., Viala, J., Chamaillard, M., Labigne, A., Thomas, G., Philpott, D.J., Sansonetti, P.J. (2003). Nod2 is a general sensor of peptidoglycan through muramyl dipeptide (MDP) detection. Journal of Biological Chemistry, 278, 8869-8872.

https://doi.org/10.1074/jbc.C200651200

Gıda, Tarım ve Hayvancılık Bakanlığı (2011). Türk gıda kodeksi etiketleme yönetmeliği.

http://www.resmigazete.gov.tr/eski-

ler/2011/12/20111229M3-7.htm (Erişim tarihi 28.01.2019)

Gleeson, J.P. (2017). Diet, food components and the intestinal barrier. Nutrition Bulletin, 42(2), 123-131.

https://doi.org/10.1111/nbu.12260
Gotteland, M., Brunser, O., Cruchet, S. (2006). Systematic review: Are probiotics useful in controlling gastric colonization by Helicobacter pylori? Alimentary Pharmacology and Therapeutics, 23(8), 1077-1086.

https://doi.org/10.1111/j.1365-2036.2006.02868.x

Guarner, F., Perdigon, G., Corthier, G., Salminen, S., Koletzko, B., Morelli, L. (2005). Should yoghurt cultures be considered probiotic? British Journal of Nutrition, 93(6), 783-786.

https://doi.org/10.1079/BJN20051428

Gürsoy, O., Kınık, Ö., Gönen, İ. (2005). Probiyotikler ve gastrointestinal sağllğa etkileri. Türk Mikrobiyoloji Cemiyeti Dergisi, 35(2), 136-148.

Hafez, M., Hayes, K., Goldrick, M., Warhurst, G., Grencis, R., Roberts, I.S. (2009). The K5 capsule of Escherichia coli strain Nissle 1917 is important in mediating interactions with intestinal epithelial cells and chemokine induction. Infection and Immunity, 77(7), 2995-3003.

https://doi.org/10.1128/IAI.00040-09

Hevia, A., Delgado, S., Sánchez, B., Margolles, A. (2015). Molecular players involved in the interaction between beneficial bacteria and the immune system. Frontiers in Microbiology, 6, 1-8.

https://doi.org/10.3389/fmicb.2015.01285

Hirose, Y., Murosaki, S., Fujiki, T., Yamamoto, Y., Yoshikai, Y., Yamashita, M. (2010). Lipoteichoic acids on Lactobacillus plantarum cell surfaces correlate with induction of interleukin-12p40 production. Microbiology and Immunology, 54(3), 143-151.

https://doi.org/10.1111/j.1348-0421.2009.00189.x

Hoveyda, N., Heneghan, C., Mahtani, K.R., Perera, R., Roberts, N., Glasziou, P. (2009). A systematic review and meta-analysis: Probiotics in the treatment of irritable bowel syndrome. BMC Gastroenterology, 9(15), 1-11. https://doi.org/10.1186/1471-230X-9-15

Hynönen, U., Palva, A. (2013). Lactobacillus surface layer proteins: Structure, function and applications. Applied Microbiology and Biotechnology, 97(12), 5225-5243. 
https://doi.org/10.1007/s00253-013-4962-2

Ivanov, D., Emonet, C., Foata, F., Affolter, M., Delley, M., Fisseha, M., Blum-Sperisen, S., Kochhar, S., Arigoni, F. (2006). A serpin from the gut bacterium Bifidobacterium longum inhibits eukaryotic elastase-like serine proteases. Journal of Biological Chemistry, 281, 17246-17252.

https://doi.org/10.1074/jbc.M601678200

Johnson-Henry, K.C., Hagen, K.E., Gordonpour, M., Tompkins, T.A., Sherman, P.M. (2007). Surface-layer protein extracts from Lactobacillus helveticus inhibit enterohaemorrhagic Escherichia coli O157:H7 adhesion to epithelial cells. Cellular Microbiology, 9(2), 356-367.

https://doi.org/10.1111/j.1462-5822.2006.00791.x

Kaji, R., Kiyoshima-Shibata, J., Nagaoka, M., Nanno, M., Shida, K. (2010). Bacterial Teichoic Acids Reverse Predominant IL-12 Production Induced by Certain Lactobacillus Strains into Predominant IL-10 Production via TLR2-Dependent ERK Activation in Macrophages. The Journal of Immunology, ji_0901569, 1-9.

https://doi.org/10.4049/jimmunol.0901569

Kalliomäki, M.A., Isolauri, E. (2004). Probiotics and downregulation of the allergic response. Immunology and Allergy Clinics of North America, 24(4), 739-752.

https://doi.org/10.1016/i.iac.2004.06.006

Kang, H., Im, S. (2015). Probiotics as an Immune Modulator. Journal of Nutritional Science and Vitaminology, 61, 103-105.

https://doi.org/10.3177/jnsv.61.S103

Kawai, T., Akira, S. (2011). Toll-like Receptors and Their Crosstalk with Other Innate Receptors in Infection and Immunity. Immunity, 34(5), 637-650.

https://doi.org/10.1016/j.immuni.2011.05.006

Kelesidis, T., Pothoulakis, C. (2012). Efficacy and safety of the probiotic Saccharomyces boulardii for the prevention and therapy of gastrointestinal disorders. Therapeutic Advances in Gastroenterology, 5(2), 111-125.

https://doi.org/10.1177/1756283X11428502
Khazaie, K., Zadeh, M., Khan, M.W., Bere, P., Gounari, F., Dennis, K., Blatner, N.R., Owen, J.L., Klaenhammer, T.R., Mohamadzadeh, M. (2012). Abating colon cancer polyposis by Lactobacillus acidophilus deficient in lipoteichoic acid. Proceedings of the National Academy of Sciences, 109(26), 10462-10467.

https://doi.org/10.1073/pnas.1207230109

Kim, H., Lee, S., Kim, N., Ko, M., Lee, J., Yi, T., Chung, S.K., Chung, D. (2008). Inhibitory effects of Lactobacillus plantarum lipoteichoic acid (LTA) on Staphylococcus aureus LTA-induced tumor necrosis factor-alpha production. Journal of Microbiology and Biotechnology, 18(6), 1191-1996.

Kleerebezem, M., Binda, S., Bron, P.A., Gross, G., Hill, C., van Hylckama Vlieg, J.E., Lebeer, S., Satokari, R., Ouwehand, A.C. (2019). Understanding mode of action can drive the translational pipeline towards more reliable health benefits for probiotics. Current Opinion in Biotechnology, $56,55-60$.

https://doi.org/10.1016/j.copbio.2018.09.007

Kleerebezem, M., Hols, P., Bernard, E., Rolain, T., Zhou, M., Siezen, R.J., Bron, P.A. (2010). The extracellular biology of the lactobacilli. FEMS Microbiology Reviews, 34(2), 199-230.

https://doi.org/10.1111/j.1574-6976.2009.00208.x

Konstantinov, S.R., Smidt, H., de Vos, W.M., Bruijns, S.C.M., Singh, S.K., Valence, F., Molle, D., Lortal, S., Altermann, E., Klaenhammer, T.R., van Kooyk, Y. (2008). $\mathrm{S}$ layer protein A of Lactobacillus acidophilus NCFM regulates immature dendritic cell and T cell functions. Proceedings of the National Academy of Sciences of the United States of America, 105(49), 19473-19478.

https://doi.org/10.1073/pnas.0810305105

Krishna Rao, R., Samak, G. (2013). Protection and Restitution of Gut Barrier by Probiotics: Nutritional and Clinical Implications. Current Nutrition and Food Science, 9(2), 99107.

https://doi.org/10.2174/1573401311309020004

Kumar, H., Kawai, T., Akira, S. (2011). Pathogen Recognition by the Innate Immune System. International Reviews of Immunology, 30(1), 16-34. 
https://doi.org/10.3109/08830185.2010.529976

Kumar, M., Kumar, A., Nagpal, R., Mohania, D., Behare, P., Verma, V., Kumar, P., Poddar, D., Aggarwal, P.K., Henry, C.J.K., Jain, S., Yadav, H. (2010). Cancer-preventing attributes of probiotics: An update. International Journal of Food Sciences and Nutrition, 61(5), 473-496.

https://doi.org/10.3109/09637480903455971

Kumar, H., Kawai, T., Shizuo, A. (2009). Toll-like receptors and innate immunity. Biochemical and Biophysical Research Communications, 388(4), 621-625.

https://doi.org/10.1016/j.bbrc.2009.08.062

Lebeer, S., Claes, I., Tytgat, H.L.P., Verhoeven, T.L.A., Marien, E., von Ossowski, I., Reunanen, J., Palva, A., de Vos, W.M., De Keersmaecker, S.C.J., Vanderleyden, J. (2012). Functional analysis of lactobacillus rhamnosus GG pili in relation to adhesion and immunomodulatory interactions with intestinal epithelial cells. Applied and Environmental Microbiology, 78(1), 185-193.

https://doi.org/10.1128/AEM.06192-11

Lebeer, S., Claes, I.J.J., Verhoeven, T.L.A., Vanderleyden, J., De Keersmaecker, S.C.J. (2011). Exopolysaccharides ofLactobacillus rhamnosusGGform a protective shield against innate immunefactors in the intestine. Microbial Biotechnology, 4(3), 368-374.

https://doi.org/10.1111/j.1751-7915.2010.00199.x

Lebeer, S., Vanderleyden, J., De Keersmaecker, S.C.J. (2008). Genes and Molecules of Lactobacilli Supporting Probiotic Action. Microbiology and Molecular Biology Reviews, 72(4), 728-764.

https://doi.org/10.1128/MMBR.00017-08

Lee, I.C., Tomita, S., Kleerebezem, M., Bron, P.A. (2013). The quest for probiotic effector molecules - Unraveling strain specificity at the molecular level. Pharmacological Research, 69(1), 61-74.

https://doi.org/10.1016/j.phrs.2012.09.010

Lightfoot, Y.L., Selle, K., Yang, T., Goh, Y.J., Sahay, B., Zadeh, M., Owen, J.L., Colliou, N., Li, E., Johannssen, T., Lepenies, B., Klaenhammer, T.R., Mohamadzadeh, M.
(2015). SIGNR3-dependent immune regulation by Lactobacillus acidophilus surface layer protein $\mathrm{A}$ in colitis. The EMBO Journal, 34(7), 881-895.

https://doi.org/10.15252/embj.201490296

Macfarlane, G.T., Cummings, J.H. (2002). Probiotics, Infection and Immunity. Current Opinion in Infectious Diseases, 15(5), 501-506.

https://doi.org/10.1097/00001432-200210000-00008

Matsuguchi, T., Takagi, A., Matsuzaki, T., Nagaoka, M., Ishikawa, K., Yokokura, T., Yoshikai, Y. (2003). Lipoteichoic Acids from Lactobacillus Strains Elicit Strong Tumor Necrosis Factor Alpha-Inducing Activities in Macrophages through Toll-Like Receptor 2. Clinical and Diagnostic Laboratory Immunology, 10(2), 259-266.

https://doi.org/10.1128/CDLI.10.2.259-266.2003

Matsuki, T., Pe, T. (2013). Epithelial Cell Proliferation Arrest Induced by Lactate and Acetate from Lactobacillus casei and Bifidobacterium breve. PLoS One, 8(4), 1-8.

https://doi.org/10.1371/journal.pone.0063053

Matsumoto, S., Hara, T., Hori, T., Mitsuyama, K., Nagaoka, M., Tomiyasu, N., Suzuki, A., Sata, M. (2005). Probiotic Lactobacillus-induced improvement in murine chronic inflammatory bowel disease is associated with the down-regulation of pro-inflammatory cytokines in lamina propria mononuclear cells. Clinical and Experimental Immunology, 140(3), 417-426.

https://doi.org/10.1111/j.1365-2249.2005.02790.x

McFarland, L.V. (2006). Meta-analysis of probiotics for the prevention of antibiotic associated diarrhea and the treatment of Clostridium difficile disease. American Journal of Gastroenterology, 101, 812-822.

https://doi.org/10.1111/j.1572-0241.2006.00465.x

Meijerink, M., Van Hemert, S., Taverne, N., Wels, M., de Vos, P., Bron, P.A., Savelkoul, F., van Bilsen, J., Kleerebezem, M., Wells, J.M. (2010). Identification of genetic loci in Lactobacillus plantarum that modulate the immune response of dendritic cells using comparative genome hybridization. PLoS One, 5(5), e10632.

https://doi.org/10.1371/journal.pone.0010632 
Melmed, G., Thomas, L.S., Lee, N., Tesfay, S.Y., Lukasek, K., Michelsen, K.S., Zhou, Y., Hu, B., Arditi, M., Abreu, M.T. (2003). Human Intestinal Epithelial Cells Are Broadly Unresponsive to Toll-Like Receptor 2-Dependent Bacterial Ligands: Implications for Host-Microbial Interactions in the Gut. The Journal of Immunology, 170(3), 1406-1415.

https://doi.org/10.4049/jimmunol.170.3.1406

Meng, J., Zhu, X., Gao, S.M., Zhang, Q.X., Sun, Z., Lu, R.R. (2014). Characterization of surface layer proteins and its role in probiotic properties of three Lactobacillus strains. International Journal of Biological Macromolecules, 65, $110-114$.

https://doi.org/10.1016/j.ijbiomac.2014.01.024

Mohamadzadeh, M., Pfeiler, E.A., Brown, J.B., Zadeh, M., Gramarossa, M., Managlia, E., Bere, P., Sarraj, B., Khan, M.W., Pakanati, K.C., Ansari, M.J., O'Flaherty, S., Barrett, T., Klaenhammer, T.R. (2011). Regulation of induced colonic inflammation by Lactobacillus acidophilus deficient in lipoteichoic acid. PNAS, 108(1), 4623-4630. https://doi.org/10.1073/pnas.1005066107

Mozzi, F., Gerbino, E., Font De Valdez, G., Torino, M.I. (2009). Functionality of exopolysaccharides produced by lactic acid bacteria in an in vitro gastric system. Journal of Applied Microbiology, 107(1), 56-64.

https://doi.org/10.1111/j.1365-2672.2009.04182.x

Murofushi, Y., Villena, J., Morie, K., Kanmani, P., Tohno, M., Shimazu, T., Aso, H., Suda, Y., Hashiguchi, K., Saito, T., Kitazawa, H. (2015). The toll-like receptor family protein RP105/MD1 complex is involved in the immunoregulatory effect of exopolysaccharides from Lactobacillus plantarum N14. Molecular Immunology, 64(1), 63-75. https://doi.org/10.1016/j.molimm.2014.10.027

Nagpal, R., Yadav, H., Kumar, M., Jain, S., Yamashiro, Y., Marotta, F. (2014). Probiotics, Prebiotics and Synbiotics: An Introduction. İçinde S. Ötleş (Eds.). Probiotics and Prebiotics in Food, Nutrition and Health (s. 1-24). Boca Raton: Taylor \& Francis Group. ISNB 13: 978-1-4665-8624-6 https://doi.org/10.1201/b15561-2

Neuhaus, F. C., Baddiley, J. (2003). A Continuum of Anionic Charge: Structures and Functions of D-Alanyl-Teichoic
Acids in Gram-Positive Bacteria. Microbiology and Molecular Biology Reviews, 67(4), 686-723.

https://doi.org/10.1128/MMBR.67.4.686-723.2003

Ogura, Y., Bonen, D.K., Inohara, N., Nicolae, D.L., Chen, F.F., Ramos, R., Britton, H., Moran, T., Karaliuskas, R., Duerrk, R.H., Achkar, J.-P., Brant, S.R., Bayless, T.M., Kirschner, B.S., Hanauer, S,B., Nuñez, G.N., Cho, J.H. (2001). A frameshift mutation in NOD2 associated with susceptibility to Crohn's disease. Nature, 411, 603-606.

https://doi.org/10.1038/35079114

Otte, J.M., Podolsky, D.K. (2004). Functional modulation of enterocytes by gram-positive and gram-negative microorganisms. American Journal of Physiology-Gastrointestinal and Liver Physiology, 286(4), G613-G626.

https://doi.org/10.1152/ajpgi.00341.2003

Ouwehand, A.C., Salminen, S., Isolauri, E. (2002). Probiotics : an overview of beneficial effects. Antonie van Leeuwenhoek, 82, 279-289.

https://doi.org/10.1023/A:1020620607611

Pandey, K.R., Naik, S.R., Vakil, B.V. (2015). Probiotics, prebiotics and synbiotics- a review. Association of Food Scientists and Technologists, 52(12), 7577-7587.

https://doi.org/10.1007/s13197-015-1921-1

Parvez, S., Malik, K.A., Ah Kang, S., Kim, H.Y. (2006). Probiotics and their fermented food products are beneficial for health. Journal of Applied Microbiology, 100(6), 11711185 .

https://doi.org/10.1111/j.1365-2672.2006.02963.x

Rafter, J. (2002). Lactic acid bacteria and cancer: mechanistic perspective. British Journal of Nutrition, 88(1), 89-94. https://doi.org/10.1079/BJN2002633

Reunanen, J., von Ossowski, I., Hendrickx, A.P.A., Palva, A., de Vosa, W.M. (2012). Characterization of the SpaCBA pilus fibers in the probiotic Lactobacillus rhamnosus GG. Applied and Environmental Microbiology, 78(7), 2337-2344. https://doi.org/10.1128/AEM.07047-11 
Rodgers, S. (2008). Novel applications of live bacteria in food services: probiotics and protective cultures. Trends in Food Science and Technology, 19(4), 188-197.

https://doi.org/10.1016/j.tifs.2007.11.007

Ruas-Madiedo, P., Medrano, M., Salazar, N., De Los Reyes-Gavilán, C.G., Pérez, P.F., Abraham, A.G. (2010). Exopolysaccharides produced by Lactobacillus and Bifidobacterium strains abrogate in vitro the cytotoxic effect of bacterial toxins on eukaryotic cells. Journal of Applied Microbiology, 109(6), 2079-2086.

https://doi.org/10.1111/j.1365-2672.2010.04839.x

Ruiz, L., Hevia, A., Bernardo, D., Margolles, A., Sánchez, B. (2014). Extracellular molecular effectors mediating probiotic attributes. FEMS Microbiology Letters, 359(1), 1-11. https://doi.org/10.1111/1574-6968.12576

Rupa, P., Mine, Y. (2012). Recent advances in the role of probiotics in human In flammation and gut health. Journal of Agricultural and Food Chemistry, 60(34), 8249-8256. https://doi.org/10.1021/jf301903t

Saber, R., Zadeh, M., Pakanati, K.C., Bere, P., Klaenhammer, T., Mansour, M. (2011). Lipoteichoic acid-deficient Lactobacillus acidophilus regulates downstream signals. Immunotherapy, 3(3), 337-347.

https://doi.org/10.2217/imt.10.119

Sağdıç, O., Küçüköner, E., Özçelik, S. (2004). Probiyotik ve Prebiyotiklerin Fonksiyonel Özellikleri. Atatürk Üniversitesi Ziraat Fakültesi Dergisi, 35(3-4), 221-228.

Sarkar, A., Mandal, S. (2016). Bifidobacteria-Insight into clinical outcomes and mechanisms of its probiotic action. Microbiological Research, 192, 159-171.

https://doi.org/10.1016/j.micres.2016.07.001

Sarkar, S. (2013). Probiotics as functional foods: gut colonization and safety concerns. Nutrition and Food Science, 43(5), 496-504.

https://doi.org/10.1108/NFS-10-2011-0120

Schell, M.A., Karmirantzou, M., Snel, B., Vilanova, D., Berger, B., Pessi, G., Zwahlen, M.-C., Desiere, F., Bork,
P., Delley, M., Pridmore, R.D., Arigoni, F. (2002). The genome sequence of Bifidobacterium longum reflects its adaptation to the human gastrointestinal tract. Proceedings of the National Academy of Sciences, 99(22), 14422-14427. https://doi.org/10.1073/pnas.212527599

Schlee, M., Harder, J., Köten, B., Stange, E.F., Wehkamp, J., Fellermann, K. (2008). Probiotic lactobacilli and VSL\#3 induce enterocyte $\beta$-defensin 2. Clinical and Experimental Immunology, 151(3), 528-535.

https://doi.org/10.1111/j.1365-2249.2007.03587.x

Schlee, M., Wehkamp, J., Altenhoefer, A., Oelschlaeger, T.A., Stange, E.F., Fellermann, K. (2007). Induction of human $\beta$-defensin 2 by the probiotic Escherichia coli Nissle 1917 is mediated through flagellin. Infection and Immunity, 75(5), 2399-2407.

https://doi.org/10.1128/IAI.01563-06

Seth, A., Yan, F., Polk, D.B., Rao, R.K. (2008). Probiotics ameliorate the hydrogen peroxide-induced epithelial barrier disruption by a PKC- and MAP kinase-dependent mechanism. American Journal of Physiology-Gastrointestinal and Liver Physiology, 294(4), 1060-1069.

https://doi.org/10.1152/ajpgi.00202.2007

Sheil, B., Shanahan, F., O'Mahony, L. (2007). Probiotic effects on inflammatory bowel disease. The Journal of Nutrition, 137(3), 819-824.

https://doi.org/10.1093/jn/137.3.819S

Shida, K., Kiyoshima-Shibata, J., Kaji, R., Nagaoka, M., Nanno, M. (2009). Peptidoglycan from lactobacilli inhibits interleukin-12 production by macrophages induced by Lactobacillus casei through Toll-like receptor 2-dependent and independent mechanisms. Immunology, 128(1pt2), 858-869. https://doi.org/10.1111/j.1365-2567.2009.03095.x

Singh, K., Kallali, B., Kumar, A., Thaker, V. (2011). Probiotics: A review. Asian Pacific Journal of Tropical Biomedicine, 1(2), 287-290.

https://doi.org/10.1016/S2221-1691(11)60174-3

Sudha, R.M., Bhonagiri, S. (2012). Efficacy of Bacillus Coagulans Strain Unique Is-2 in the Treatment of Patients With 
Acute Diarrhea. International Journal of Probiotics and Prebiotics, 7(1), 33-37.

Tabasco, R., Fernández, P., Palencia, D., Fontecha, J., Peláez, C., Requena, T. (2014). Competition mechanisms of lactic acid bacteria and bi fi dobacteria : Fermentative metabolism and colonization. LWT - Food Science and Technology, 55(2), 680-684.

https://doi.org/10.1016/j.lwt.2013.10.004

Tanaka, Y., Kanazawa, M., Fukudo, S., Drossman, D.A. (2011). Biopsychosocial model of irritable bowel syndrome. Journal of Neurogastroenterology and Motility, 17(2), 131139.

https://doi.org/10.5056/jnm.2011.17.2.131

Tsilingiri, K., Rescigno, M. (2013). Postbiotics : what else?. Beneficial Microbes, 4(1), 101-107.

https://doi.org/10.3920/BM2012.0046

Turroni, F., Serafini, F., Foroni, E., Duranti, S., O'Connell Motherway, M., Taverniti, V., Mangifesta, M., Milani, C., Viappiani, A., Roversi, T., Sánchez, B., Santoni, A., Gioiosa, L., Ferrarini, A., Delledonne, M., Margolles, A., Piazza, L., Palanza, P., Bolchi, A., Guglielmetti, S., van Sinderen, D., Ventura, M. (2013). Role of sortase-dependent pili of Bifidobacterium bifidum PRL2010 in modulating bacterium-host interactions. Proceedings of the National Academy of Sciences of the United States of America, 110(27), 11151-11156.

https://doi.org/10.1073/pnas. 1303897110

Tytgat, H.L.P., Douillard, F.P., Reunanen, J., Rasinkangas, P., Hendrickx, A.P.A., Laine, P.K., Paulin, L., Satokari, R., Vos, W.M. de. (2016). Lactobacillus rhamnosus GG Outcompetes Enterococcus faecium via Mucus-Binding Pili: Evidence for a Novel and Heterospecific Probiotic Mechanism. Applied and Environmental Microbiology, 82(19), 5756-5762.

https://doi.org/10.1128/AEM.01243-16

Van Hemert, S., Meijerink, M., Molenaar, D., Bron, P. A., De Vos, P., Kleerebezem, M., Wells, J., M. Marco, M. L. (2010). Identification of Lactobacillus plantarum genes modulating the cytokine response of human peripheral blood mononuclear cells. BMC Microbiology, 10(293), 1-13. https://doi.org/10.1186/1471-2180-10-293

Vargas García, C.E., Petrova, M., Claes, I.J.J., De Boeck, I., Verhoeven, T.L.A., Dilissen, E., Von Ossowski, I., Palva, A., Bullens, D.M., Vanderleyden, J., Lebeer, S. (2015). Piliation of Lactobacillus rhamnosus GG promotes adhesion, phagocytosis, and cytokine modulation in macrophages. Applied and Environmental Microbiology, 81(6), 2050-2062.

https://doi.org/10.1128/AEM.03949-14

Veerappan, G.R., Betteridge, J., Young, P.E. (2012). Probiotics for the treatment of inflammatory bowel disease. Current Gastroenterology Reports, 14(4), 324-333.

https://doi.org/10.1007/s11894-012-0265-5

Vidal, K., Donnet-Hughes, A., Granato, D. (2002). Lipoteichoic Acids from Lactobacillus johnsonii Strain Lal and Lactobacillus acidophilus Strain La10 Antagonize the Responsiveness of Human Intestinal Epithelial HT29 Cells to Lipopolysaccharide and Gram-Negative Bacteria. Infection and Immunity, 70(4), 2057-2064.

https://doi.org/10.1128/IAI.70.4.2057-2064.2002

Villena, J., Alvarez, S., Kitazawa, H. (2013). Introduction. İçinde Kitazawa, H., Villena, J. ve Alvarez, S. (Eds.), Probiotics: Immunobiotica And Immunogenics (s. 1-11). Boca Raton: Taylor \& Francis Group. ISNB 978-1-4822-0685-2 https://doi.org/10.1201/b15532-2

Von Schillde, M.A., Hörmannsperger, G., Weiher, M., Alpert, C.A., Hahne, H., Bäuerl, C., Van Huynegem, K., Steidler, L., Hrncir, T., Pérez-Martínez, G., Kuster, B., Haller, D. (2012). Lactocepin secreted by Lactobacillus exerts anti-inflammatory effects by selectively degrading proinflammatory chemokines. Cell Host and Microbe, 11(4), 387-396.

https://doi.org/10.1016/j.chom.2012.02.006

Wu, M.H., Tzu-Ming P., Yu-Jen, W., Chang, S.J., Chang, M.S., Hu, C.Y. (2010). Exopolysaccharide activities from probiotic bifidobacterium: Immunomodulatory effects (on J774A. 1 macrophages) and antimicrobial properties. International Journal of Food Microbiology, 144(1), 104-110. https://doi.org/10.1016/j.ijfoodmicro.2010.09.003 
Yan, F., Liu, L., Dempsey, P.J., Tsai, Y.H., Raines, E.W., Wilson, C.L., Cao, H., Cao, Z., Liu, L., Polk, D.B. (2013). A lactobacillus rhamnosus GG-derived soluble protein, p40, stimulates ligand release from intestinal epithelial cells to transactivate epidermal growth factor receptor. Journal of Biological Chemistry, 288(42), 30742-30751.

https://doi.org/10.1074/jbc.M113.492397

Yan, F., Cao, H., Cover, T.L., Whitehead, R., Washington, M.K., Polk, D.B. (2007). Soluble proteins produced by probiotic bacteria regulate intestinal epithelial cell sur vival and growth. Gastroenterology, 132(2), 562-575.

https://doi.org/10.1053/j.gastro.2006.11.022

Yasuda, E., Serata, M., Sako, T. (2008). Suppressive effect on activation of macrophages by Lactobacillus casei strain shirota genes determining the synthesis of cell wall-associated polysaccharides. Applied and Environmental Microbiology, 74(15), 4746-4755.

https://doi.org/10.1128/AEM.00412-08 